\title{
THE STATUS OF Silurus wynaAdensis DAY (SILURIDAE: PISCES) WITH A NOTE ON ITS BIONOMICS
}

\author{
K.C. Gopi and C. Radhakrishnan
}

Western Ghats Field Research Station, Zoological Survey of India, Annie Hall Road, Calicut, Kerala 673002, India.

\begin{abstract}
In literature Silurus wynaadensis is considered to be a Critically Endangered species. Our field studies indicate differently. Many specimens were collected from various streams of Wynad and Kasargod districts of Kerala. The nocturnal habit and reserved nature of the species must have made it difficult for earlier researchers to collect it during their surveys. Taxonomically, main features of the specimens matched with the species characteristics of $S$. wynaadensis shown by Kobayakawa (1989) except in the meristic counts of mandibular barbels and anal finrays. The species studied had one or two pairs of mandibular barbels and 58-62 anal fin rays instead of two pairs of madibular barbels and 56 anal fin rays
\end{abstract}

\section{Keywords}

Silurus wynaadensis, status, bionomics, taxonomy, freshwater fish, Kerala

\section{Introduction}

Day (1873) described the catfish, Silurus wynaadensis based on the specimen collected from an upstream of the Cauvery Drainage System in Wynad, Kerala. Subsequent reports were limited to that of Bhimachar and Rau (1941) from the Jagger Valley of the Tungabhadra Drainage System in Karnataka, Rajan (1955) from the headwaters of Bhavani River of Cauvery Drainage System, Gopi (1996) from the upstream waters of the west flowing Chandragiri River in northern Kerala, Rema Devi et al. (1997) from the Tambraparani River in southern Tamil Nadu and Arunachalam et al. (2000) from Neerar River in Satara District, Maharashtra. S. wynaadensis is considered to be a rare species due to its very scarce availability within its range of geographic distribution. It has eluded ichthyological explorers in most of their attempts, which inclined them to consider this fish as a Critically Endangered species (Molur \& Walker, 1998; Shaji \& Easa, 1998). The Conservation
Assessment and Management Plan workshop (CAMP) conducted in 1997 assessed the species as Critically Endangered due to its restricted distribution in Kerala (Molur \& Walker, 1998).

\section{Observations \\ Bionomics}

Our field surveys culminated in the collection of 16 specimens of S. wynaadensis (fig. 1) from the Kalindhi Rivulet of Kabani River (Cauvery Drainage System) near Thirunelly in Wynad and from the upstream of Chandragiri Drainage System near Ranipuram in Kasaragod of Kerala. We also identified one specimen of the species from a sample lot of fish collected from Vythiripuzha in Wynad (Kuttiyadi Drainage System). Our observations facilitated to understand some aspects of bionomics of the species.

In the faunistic survey of Wynad, the specimens were collected from a rocky water pool within a much-depleted stream in the midst of a comparatively undisturbed forest locality near Thirunelly. When the content of the pool consisting of submerged leaf debris, with apparently no sign of fish life but of active aquatic insect life, was scooped out and sorted, two specimens of the fish were exposed and collected. The bottom of the pit contained loose sand, gravel and silt besides decaying leaf debris.

Subsequent collections were made from upstream habitats of the Chandragiri River Drainage at Ranipuram forest locality near Kanhangad in Kasaragod. The riparian habitat in the collection site constituted vegetation comprising of forest and homestead plantations. Failing to make any collection of the species during daytime and suspecting its nocturnal habits, the survey team made a venture in the night between 2200 and $2330 \mathrm{hr}$, under the illumination of dry-celled torches. Deep pools in the stream bed, which appeared to be devoid of this fish during daytime, were found harbouring a good number of specimens foraging in the surface of the water. With the help of local people we 


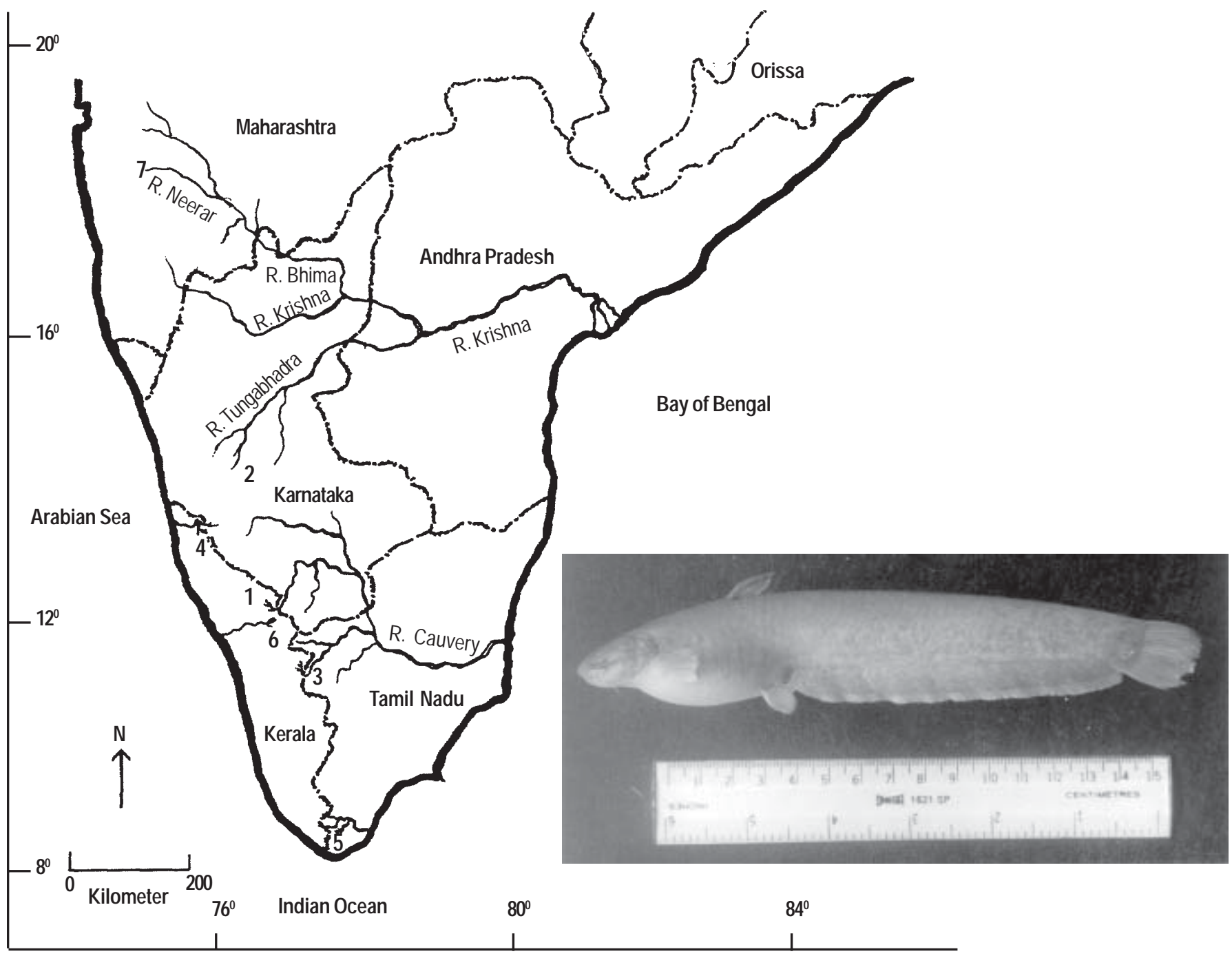

Figure 1. Map showing the distribution of Silurus wynaadensis Day

Key: Upstreams of Rivers: 1 - Kabani; 2 - Tungabhadra; 3 - Bhavani; 4 - Chandragiri; 5 - Tambraparani; 6. Vythiri; 7 - Neerar

could easily collect samples of fully-grown adult specimens $(15-25 \mathrm{~cm})$ using line and hook baited with earthworm. $S$. wynaadensis is thus, nocturnal in habit, at the same time very reclusive during the day. This possibly explains why this fish is seldom or very rarely found in collection surveys.

Another sample of specimens was collected from the same locality with the assistance of local people. The local people with their unmistaken identity of $S$. wynaadensis, mention that the fish found only in the upstream of the river and not in its midland course below $600 \mathrm{~m}(2000 \mathrm{ft})$, is habituated to spawnrun immediately after the onset of monsoon in search of clean oxygenated spring water sources. During this phase, the fish often comes to shallow water in submerged cultivable fields amidst the riparian vegetation for spawning during night and gets back to the stream-riverine habitats before dawn. Sometimes the specimens are trapped in the isolated irrigation wells dug in the field. During the breeding season of this fish, people often catch them for consumption.

\section{Taxonomy}

Kobayakawa (1989) reviewed taxonomic status and zoogeography of the genus Silurus. According to her, of the 17 species known under the genus Silurus, S. wynaadensis is the only species found within Indian limits. 
The specimens in our collections were easily differentiated by the following characteristics: dorsal fin rays 4 ; pectoral fin rays 1,10 ; pelvic fin rays i, 7 ; anal fin rays 58-62 (ii, 56-60); vertebrae $13+39=52$ (count based on dissection of one specimen, $18 \mathrm{~cm}$ long); upper jaw longer than lower; vomerine teeth in two separate patches; mandibular barbels two pairs (often one pair only); maxillary barbels one pair extending over pectoral fin, but not reaching base of pelvic fins; caudal fin rounded. These salient features tallied with the species characteristics of $S$. wynaadensis shown by Kobayakawa (1989: 174) and, Talwar and Jhingran (1991: 589), except in the meristic characters of mandibular barbels and anal fin rays. The species studied by us were observed to have one or two pairs of mandibular barbels and 58-62 anal fin rays, instead of two mandibular pairs and 56 anal fin rays respectively, as noted by Kobayakawa (1989).

Day (1875-78) in his description of $S$. wynaadensis has mentioned two pairs of mandibular barbels. Bhimachar and Rau (1941) observed variation in number of mandibular barbels, some specimens with two pairs and others with one pair. They adduced that the variability found in the number of mandibular barbels in Silurus is due to the atrophy of one of the pairs during the growth and development of the fish and, therefore, it has no taxonomic significance. Of the 16 specimens available with us, only two young ones exhibit two pairs of mandibular barbels and all others, notably adult ones, have only one pair in conformity with the observation made by Bhimachar and Rau (1941). Day (1875-78) has also mentioned 58-62 (ii, 56-60) anal fin rays for the species which is identical to the count of anal fin rays observed on the specimens in our collection. Hence, the count-range of anal fin rays of $S$. wynaadensis is to be taken as 56-62 (ii, 56-60).

\section{Materials examined}

14 exs., 10-ix-1993, 7.vii.1996 and 18.v.1998, Ranipuram (upstream of Chandragiri Drainage), Kanhangad, Kasaragod District, Kerala, Coll. K.C. Gopi \& party.

Two exs., 22.iii.1995, Thirunelly (Kalindhi rivulet, Kabani River), Wynad District, Kerala, Coll. K.C. Gopi \& party.

One ex. (received for identification), 11.vii.1995, Vythiripuzha, Wynad District, Kerala, Coll. C. Pramod \& party.

\section{Discussion}

Based on the distributional pattern (Fig. 1) of the species and our observations on its population in the stream-riverine habitats particularly of the Chandragiri Drainage, it can be inferred that $S$. wynaadensis continues to exist in its range of distribution with surviving populations capable of perpetuating themselves in future. The homestead settlers in the hill areas of Kasaragod are aware of the identity as well as the upstream habitat preference (altitudinal range-specificity) of this species. They are also categorical about the relative abundance and population proliferation of the fish during monsoon season. Thus, despite its population being distributed in disjointed localities in Western Ghats, $S$. wynaadensis is not on the threshold of a drastic depletion that might lead to its extinction in a considerable span of time.

\section{Acknowledgement}

The authors are grateful to the Director, Zoological Survey of India, Calcutta for facilities and encouragement.

\section{References}

Arunachalam, M., A. Sankaranarayan, J.A. Johnson, A. Manimekalan and R. Sornam (2000). New records of fishes from the Western Ghats of Maharashtra. Journal of the Bombay Natural History Society 97(2): 292-295.

Bhimachar, B.S. and A.S. Rau (1941). The fishes of Mysore state. 1. Fishes of Kadur District. Journal of University of Mysore (B)1: 141-153.

Day, F. (1873). On new imperfectly known fishes of India. Proceedings of the Zoological Society of London: 236-240.

Day, F. (1875-78). The fishes of India: being a natural history of the fishes known to inhabit the seas and freshwaters of India, Burma and Ceylon. Text and atlas in 4 parts. London, $\mathrm{xx}+778$ pp., 195 pls.

Devi, R.K., T.J. Indra, M.B. Raghunathan, M.M. Bai and M.S. Ravichandran (1997). lchthyofauna of the Thambraparani River System, Tamil Nadu. Zoos'Print 12(7): 1-2.

Gopi, K.C. (1996). Extension of range of Silurus wynaadensis Day (Pisces: Siluriformes: Siluridae). Journal of the Bombay Natural History Society 93(3): 592-593.

Kobayakawa, M. (1989). Systematic revision of the catfish genus Silurus with description of a new species from Thailand and Burma. Japanese Journal of Ichthyology 36(2): 155-186.

Molur, S. and S. Walker (Editors) (1998). Report of the workshop "Conservation Assessment and Managemnt Plan for Freshwater Fishes of India". Zoo Outreach Organisation, Conservation Breeding Specialist Group India, Coimbatore, $156 \mathrm{pp}$.

Rajan, S. (1955). Notes on a collection of fish from the headwaters of the Bhavani River, South India. Journal of the Bombay Natural History Society 53(1): 44-48.

Shaji, C.P. and P.S. Easa (1998). Status and distribution of endemic fresh water fishes in Kerala, Western Ghats, India. Tiger paper 25(3): 21-24.

Talwar, P.K. and A.G. Jhingran (1991). Inland fishes of India and adjacent countries. Vol. 1\&2. Oxford \& IBH Publishing Co. Pvt. Ltd., New Delhi, 1158 pp. 